\title{
Discrepancy between Measured Serum Total Carbon Dioxide Content and Bicarbonate Concentration Calculated from Arterial Blood Gases
}

\author{
Youngho Kim ${ }^{1}$, Larry Massie ${ }^{2}$, Glen H. Murata ${ }^{3}$, Antonios H. Tzamaloukas 4 \\ 1. Medicine Service, Sandoval County Regional Medical Center, Rio Rancho, New Mexico 2. Pathology \\ Service, Raymond G Murphy VA Medical Center 3. Raymond G. Murphy VA Medical Center, Albuquerque, \\ New Mexico 4. University of New Mexico School of Medicine
}

$\square$ Corresponding author: Antonios H. Tzamaloukas, antonios.tzamaloukas@va.gov Disclosures can be found in Additional Information at the end of the article

\section{Abstract}

Large differences between the concentrations of serum total carbon dioxide $\left(\mathrm{TCO}_{2}\right)$ and blood gas bicarbonate $\left(\mathrm{HCO}_{3}{ }^{-}\right)$were observed in two consecutive simultaneously drawn sets of samples of serum and arterial blood gases in a patient who presented with severe carbon dioxide retention and profound acidemia. These differences could not be explained by the effect of the high partial pressure of carbon dioxide on $\mathrm{TCO}_{2}$, by variations in the dissociation constant of the carbonic acid/bicarbonate system or by faults caused by the algorithms of the blood gas apparatus that calculate $\mathrm{HCO}_{3}{ }^{-}$. A recalculation using the Henderson-Hasselbach equation revealed arterial blood gas $\mathrm{HCO}_{3}{ }^{-}$values close to the corresponding serum $\mathrm{TCO}_{2}$ values and clarified the diagnosis of the acid-base disorder, which had been placed in doubt by the large differences between the reported $\mathrm{TCO}_{2}$ and $\mathrm{HCO}_{3}{ }^{-}$values. Human error in the calculation of $\mathrm{HCO}_{3}{ }^{-}$was identified as the source of these differences. Recalculation of blood gas $\mathrm{HCO}_{3}{ }^{-}$should be the first step in identifying the source of large differences between serum $\mathrm{TCO}_{2}$ and blood gas $\mathrm{HCO}_{3}^{-}$.

Received 09/17/2015 Review began 09/18/2015 Review ended 11/25/2015 Published 12/07/2015

\section{(c) Copyright 2015}

Kim et al. This is an open access article distributed under the terms of the Creative Commons Attribution License CC-BY 3.0., which permits unrestricted use, distribution, and reproduction in any medium, provided the original author and source are credited.
Categories: Emergency Medicine, Internal Medicine, Nephrology

Keywords: total co2 concentration, bicarbonate concentration, carbonic acid/bicarbonate pk', acidbase status, acidemia, hypercapnia, respiratory acidosis, metabolic acidosis

\section{Introduction}

The measured total carbon dioxide $\left(\mathrm{TCO}_{2}\right)$ in serum has three main components, bicarbonate anion $\left(\mathrm{HCO}_{3}{ }^{-}\right)$, dissolved carbon dioxide $\left(\mathrm{dCO}_{2}\right)$, and carbonic acid $\left(\mathrm{H}_{2} \mathrm{CO}_{3}\right)$, which is the hydrated form of carbon dioxide. The concentration of $\mathrm{dCO}_{2}$ is calculated from the partial pressure of $\mathrm{CO}_{2}\left(\mathrm{pCO}_{2}\right)$. Not taking into account the concentration of $\mathrm{H}_{2} \mathrm{CO}_{3}$ in this calculation is the source of a negligible error. In body fluids, one $\mathrm{H}_{2} \mathrm{CO}_{3}$ molecule is at equilibrium with 340 molecules of $\mathrm{dCO}_{2}$ under normal temperature and physiologic conditions [1]. At a pH of 7.40, the concentration of $\mathrm{HCO}_{3}{ }^{-}$is 20 -fold higher than the concentration of $\mathrm{dCO}_{2}$ and the 
concentration of $\mathrm{H}_{2} \mathrm{CO}_{3}$ is $1.2 / 340$ or $0.004 \mathrm{mmol} / \mathrm{L}$ when the $\mathrm{TCO}_{2}$ concentration is 25.2 $\mathrm{mmol} / \mathrm{L}$ and the $\mathrm{HCO}_{3}{ }^{-}$level is $24 \mathrm{mmol} / \mathrm{L}$. The ratio $\mathrm{HCO}_{3}{ }^{-} / \mathrm{dCO}_{2}$ decreases progressively as the $\mathrm{pH}$ decreases but remains routinely high. Consequently, the concentrations of $\mathrm{TCO}_{2}$ in a serum sample and of $\mathrm{HCO}_{3}{ }^{-}$in a simultaneously drawn blood gas sample should differ only slightly, with $\mathrm{TCO}_{2}$ typically exceeding $\mathrm{HCO}_{3}^{-}$by less than $3 \mathrm{mmol} / \mathrm{L}$.

In a sample of blood gases, the concentration of $\mathrm{dCO}_{2}$ is expressed by multiplying the $\mathrm{pCO}_{2}$ by a proportionality coefficient $S$ converting units of partial pressure to units of molar concentration. The value of $\mathrm{HCO}_{3}{ }^{-}$in blood gases is routinely obtained by entering the measured values of $\mathrm{pH}$ and $\mathrm{pCO}_{2}$ in an algorithm representing the Henderson-Hasselbach equation, the general expression of which is as follows:

$$
\mathrm{pH}=\mathrm{pK}^{\prime}+\log \left(\mathrm{HCO}_{3}^{-} /\left[\mathrm{SxpCO}_{2}\right]\right)
$$

where $\mathrm{pK}$ ' is the negative logarithm of the first dissociation constant of $\mathrm{H}_{2} \mathrm{CO}_{3}$. The general expression of $\mathrm{HCO}_{3}{ }^{-}$concentration is obtained by rearranging equation 1 as follows:

$$
\mathrm{HCO}_{3}^{-}=\operatorname{SxpCO}_{2} \mathrm{x} 10^{(\mathrm{pH}-\mathrm{pK})}
$$

The coefficient $S$ is not constant. The temperature and composition of the solution tested are factors affecting this coefficient. At body temperature, the coefficient $S$ obtains the value 0.0301 $\mathrm{mmol} / \mathrm{L}$ per $\mathrm{mm} \mathrm{Hg}$ in blood [1]. The $\mathrm{pK}^{\prime}$ of $\mathrm{H}_{2} \mathrm{CO}_{3}$ in aqueous solutions is around 3.5 [2]. The calculation of this pK' in biological fluids assumes that $\mathrm{H}_{2} \mathrm{CO}_{3}$ consists of the whole $\mathrm{dCO}_{2}$. Therefore, the apparent value of pK' is at or very close to 6.1 under normal conditions [1].

Large differences between simultaneously obtained concentrations of serum $\mathrm{TCO}_{2}$ and arterial blood $\mathrm{HCO}_{3}{ }^{-}$are encountered in certain instances. These differences complicate the evaluation of the acid-base status of patients and may lead to diagnostic and therapeutic errors. One potential source of the discrepancy is rooted in the erroneous assumption that the pK' of $\mathrm{H}_{2} \mathrm{CO}_{3}$ is constant at 6.1. It was suggested that this $\mathrm{pK}$ ' is the cause of erroneous calculation of $\mathrm{HCO}_{3}{ }^{-}$in blood gases [3].

Differences in the concentrations of closely obtained $\mathrm{TCO}_{2}$ and $\mathrm{HCO}_{3}{ }^{-}$may have other origins in addition to a wrong value of $\mathrm{pK}$ ' applied in the calculation of $\mathrm{HCO}_{3}{ }^{-}$. A systematic search for the cause of these differences is merited. We report a patient presenting with a large difference between serum $\mathrm{TCO}_{2}$ and arterial blood gas $\mathrm{HCO}_{3}{ }^{-}$in two consecutive sets of serum and blood gas samples. By our calculations, the pK' was not the cause of this difference. A different reason for the difference was detected and led to the correct diagnosis of the acid-base disturbance, which was in doubt because of the $\mathrm{TCO}_{2} / \mathrm{HCO}_{3}{ }^{-}$discrepancy.

\section{Case Presentation}

\section{Patient}

Permission to report this case was obtained from the Raymond G Murphy VA Medical 


\section{Cureus}

Center Institutional Human Research Committee. This paper was approved as a case report with waiving of the informed consent with the proviso that all identifying information was removed from the text.

A 61-year-old man with acute confusion and shallow and infrequent respirations was transferred to this hospital from a nursing home. He carried the diagnosis of alcoholic cirrhosis with ascites. One year prior to this admission, he had a small bowel resection with ileostomy. Six months later, he had surgical repair of an incarcerated inguinal hernia.

In the days prior to admission, he had consumed an unknown number of oxycodone tablets. On admission, his temperature was $36.9^{\circ} \mathrm{C}$, blood pressure - $132 / 68 \mathrm{~mm} \mathrm{Hg}$, and pulse rate - 89 per minute. Urine toxicology revealed large concentrations of opioids. Acute respiratory failure was diagnosed. He underwent tracheal intubation and was ventilated. Table 1 shows arterial blood acid-base parameters and serum $\mathrm{TCO}_{2}$ in the first two sets of simultaneously drawn samples of arterial blood gases and serum. Arterial blood gas values were determined in a satellite "pointof-care" instrument almost immediately after collection of the samples. The concentration of serum $\mathrm{TCO}_{2}$ exceeded that of arterial blood gas $\mathrm{HCO}_{3}{ }^{-}$by $10.7 \mathrm{mmol} / \mathrm{L}$ in the first set of blood samples and by $7.6 \mathrm{mmol} / \mathrm{L}$ in the second set. In the first and second serum samples, respectively, sodium concentrations were 139 and $138 \mathrm{mmol} / \mathrm{L}$, chloride concentrations were 102 and $103 \mathrm{mmol} / \mathrm{L}$, and anion gaps were 8 and $9 \mathrm{mEq} / \mathrm{L}$. Lactate level was $1.1 \mathrm{mmol} / \mathrm{L}$ in the first blood sample.

\begin{tabular}{|c|c|c|c|c|}
\hline Study & Arterial pH & Arterial $\mathrm{pCO}_{2} \mathrm{~mm} \mathrm{Hg}$ & Arterial $\mathrm{HCO}_{3}^{-} \mathrm{mmol} /$ & Serum $\mathrm{TCO}_{2} \mathrm{mmol} / \mathrm{L}$ \\
\hline 1st & 6.91 & 149 & 18.3 & 29.0 \\
\hline 2nd & 7.11 & 74 & 18.4 & 26.0 \\
\hline
\end{tabular}

\section{TABLE 1: Reported simultaneously obtained serum and arterial blood gas acid-base parameters}

The patient's respiratory acidosis improved rapidly with ventilation. He was extubated the next day. His mental status improved slowly and returned to baseline in four days. The concentration of serum $\mathrm{TCO}_{2}$ was between 24 and $27 \mathrm{mmol} / \mathrm{L}$ in samples obtained after the first two samples during this hospitalization.

\section{Investigations of the source of the discrepancy between $\mathrm{TCO}_{2}$ and $\mathrm{HCO}_{3}{ }^{-}$}

Identification of the source of the difference between serum $\mathrm{TCO}_{2}$ and arterial blood $\mathrm{HCO}_{3}{ }^{-}$ was attempted in three successive steps:

The Potential Effect of Elevated $p \mathrm{CO}_{2}$

The concentration of $\mathrm{TCO}_{2}$ is considered at first approximation to be equal to the sum of the 


\section{Cureus}

concentrations of $\mathrm{dCO}_{2}$ and $\mathrm{HCO}_{3}{ }^{-}$. Because it is a linear function of $\mathrm{pCO}_{2}, \mathrm{dCO}_{2}$ accounts for progressively larger differences between serum $\mathrm{TCO}_{2}$ and $\mathrm{HCO}_{3}{ }^{-}$at progressive levels of hypercapnia. We tested whether $\mathrm{dCO}_{2}$, calculated as $0.0301 \mathrm{XpCO}_{2}$, accounted for the differences between serum $\mathrm{TCO}_{2}$ and blood gas $\mathrm{HCO}_{3}{ }^{-}$in our patient. Figure 1 shows this comparison for the first set of measurements. The figure shows the sum of blood gas $\mathrm{HCO}_{3}{ }^{-}$, $\mathrm{dCO}_{2}$, and $\mathrm{H}_{2} \mathrm{CO}_{3}$ in an idealized normal subject with an $\mathrm{HCO}_{3}{ }^{-}$of $24 \mathrm{mmol} / \mathrm{L}$ and a $\mathrm{dCO}_{2}$ of 1.2 $\mathrm{mmol} / \mathrm{L}$ and in the first set of arterial blood gases in the patient of this report, plus the measured $\mathrm{TCO}_{2}$ in the first blood sample of this patient.

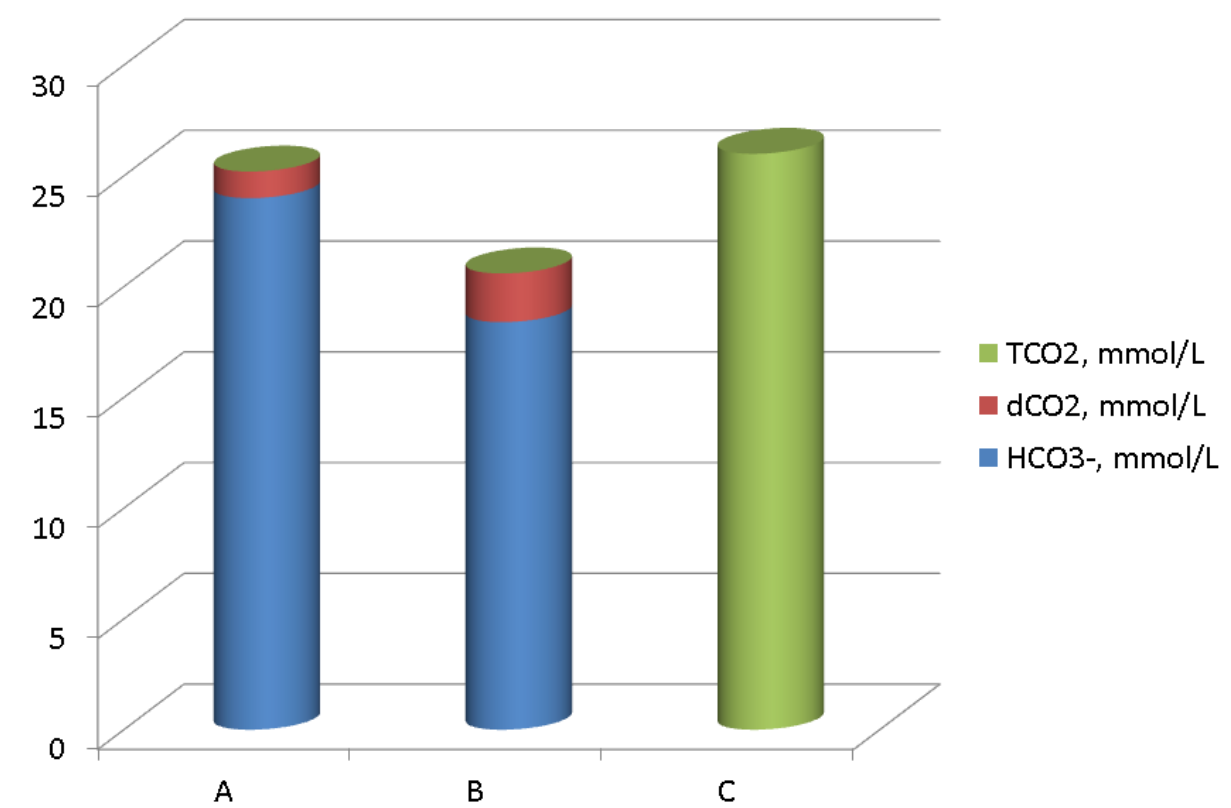

\section{FIGURE 1: Components of total carbon dioxide content}

A: Idealized normal subject. B: Arterial blood gas $\mathrm{dCO}_{2}$, plus $\mathrm{H}_{2} \mathrm{CO}_{3}$, plus $\mathrm{HCO}_{3}{ }^{-}$in the first set of blood tests in the patient presented in this report. C: Serum $\mathrm{TCO}_{2}$ in the first set of blood tests in the patient of this report. The concentration of arterial $\mathrm{dCO}_{2}$ was substantially higher in $\mathrm{B}$ than in A. Despite adjustment for the high $\mathrm{dCO}_{2}$, the measured concentration of $\mathrm{TCO}_{2}$ in serum (C) remained substantially higher than its computed concentration in the blood gasses (B).

Figure 2 shows the comparison between the sum of blood gas $\mathrm{HCO}_{3}{ }^{-}, \mathrm{dCO}_{2}$, and $\mathrm{H}_{2} \mathrm{CO}_{3}$, plus the measured serum $\mathrm{TCO}_{2}$ in the second set of measurements and in the idealized normal subject. 


\section{Cureus}

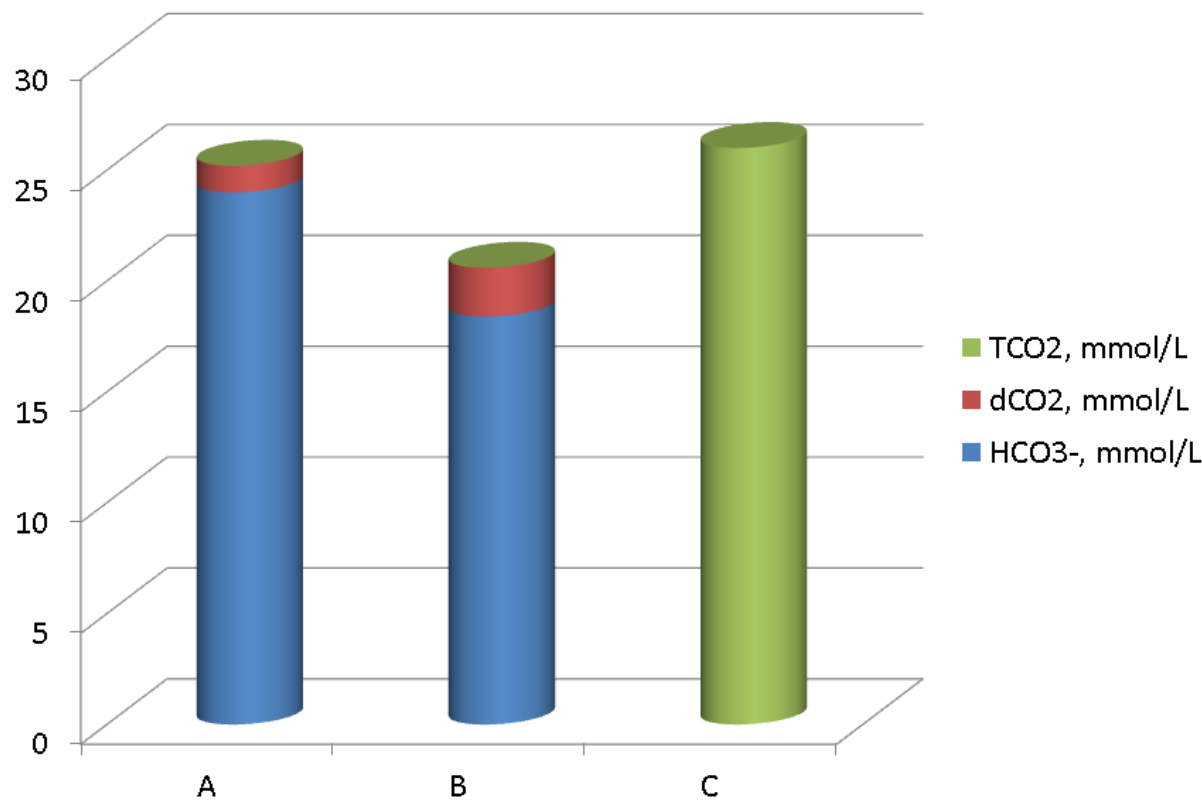

\section{FIGURE 2: Components of total Carbon dioxide content}

A. Idealized normal subjects. B. Arterial blood gas $\mathrm{HCO}_{3}{ }^{-}$, plus $\mathrm{dCO}_{2}$, plus $\mathrm{H}_{2} \mathrm{CO}_{3}$ in the second set of blood tests in the patient of this report. C. Measured serum $\mathrm{TCO}_{2}$ in the second set of blood tests in the patient of this report. The measured serum $\mathrm{TCO}_{2}(\mathrm{C})$ remained substantially higher than the calculated blood gas $\mathrm{TCO}_{2}$ (B).

Figures 1 and 2 have two noticeable findings. The first finding is that the concentration of $\mathrm{H}_{2} \mathrm{CO}_{3}$ was truly negligible. The concentration of $\mathrm{H}_{2} \mathrm{CO}_{3}$ should be shown in red. Red colour columns did not appear in the figures even at a $\mathrm{pCO}_{2}$ of $149 \mathrm{~mm} \mathrm{Hg}$. The main finding of Figures 1 and 2 is that accounting for $\mathrm{dCO}_{2}$ reduced the difference of the concentrations between serum $\mathrm{TCO}_{2}$ and arterial blood $\mathrm{HCO}_{3}{ }^{-}$but did not eliminate it. Substantial parts of this difference remained unaccounted for.

\section{Potential Effect of Changing $p K^{\prime}$}

The $\mathrm{pK}^{\prime}$ of $\mathrm{H}_{2} \mathrm{CO}_{3}$ in various solutions is not a fixed value. Variables affecting this pK' include the temperature, acidity, and ionic strength of the solution tested [3-7]. The first two variables have been studied extensively [3-6]. The pK' value increases with increasing acidity and decreasing temperature. Increasing the $\mathrm{pK}$ ' value in equation 2 lowers the value of $\mathrm{HCO}_{3}{ }^{-}$ calculated from it for the same value of $\mathrm{pCO}_{2}$. In the chapter by Madias and Cohen [1], Table 1-3 shows apparent pK' values in human plasma at temperatures between 10 and $40^{\circ} \mathrm{C}$ and $\mathrm{pH}$ values between 7.0 and 7.6. In this table, the lowest plasma pK', at a pH of 7.60 and a temperature of $40^{\circ} \mathrm{C}$, was 6.077 while the highest $\mathrm{pK}$ ', at a $\mathrm{pH}$ of 7.00 and a temperature of 10 ${ }^{\circ} \mathrm{C}$, was 6.246. Figure 3 shows the values of $\mathrm{HCO}_{3}{ }^{-}$calculated from equation 2 for a $\mathrm{pCO}_{2}$ of 149 


\section{Cureus}

$\mathrm{mm} \mathrm{Hg}$ and pK' values of 6.1, 6.077, and 6.246. The figure shows substantial differences between these values. The lowest value of $\mathrm{HCO}_{3}{ }^{-}$was calculated for a pK' of 6.246 and the highest value for a pK' of 6.077 .

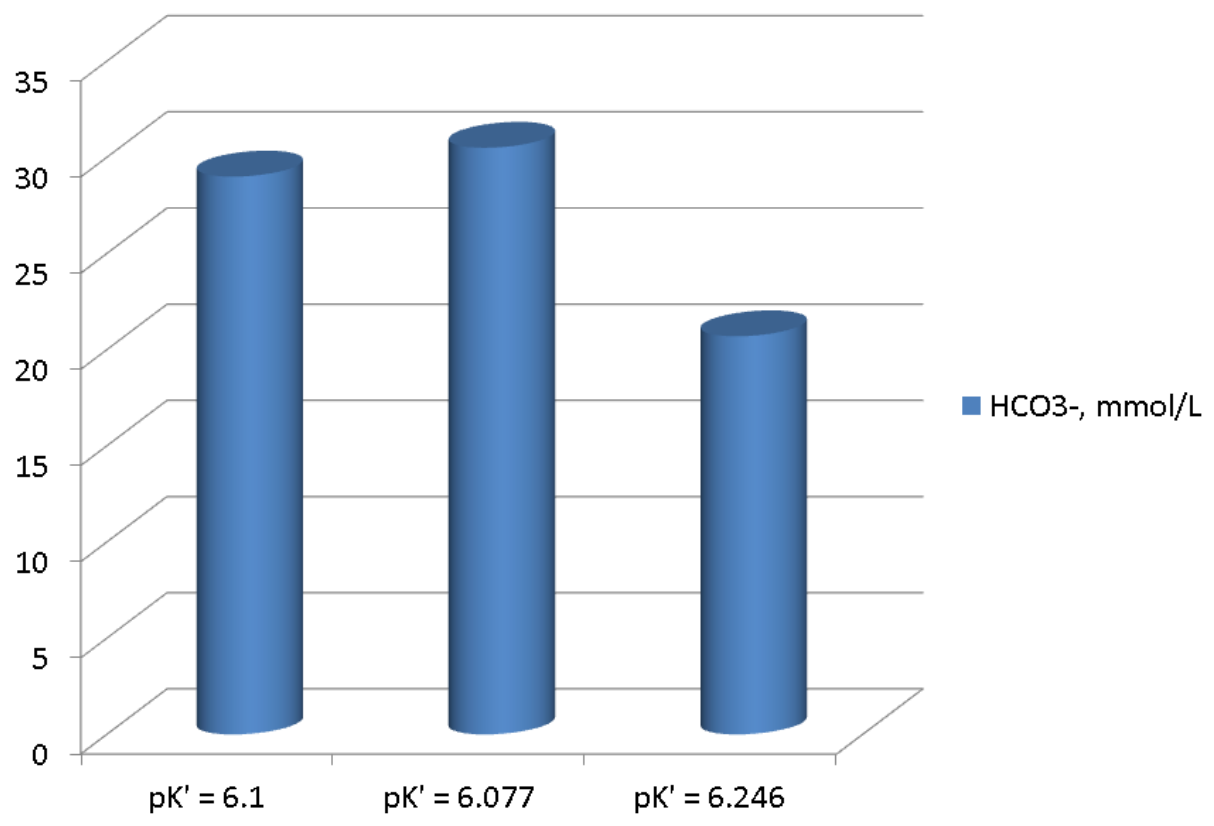

FIGURE 3: Bicarbonate values calculated at a pH of 6.91 from a pCO2 of $149 \mathrm{~mm} \mathrm{Hg}$ by various pK' values

High pK' values, observed at low temperatures and low $\mathrm{pH}$ values result in low values of calculated $\mathrm{HCO}_{3}{ }^{-}$.

The purpose of Figure 3 was to show the direction of the changes in the $\mathrm{HCO}_{3}{ }^{-}$concentration that result exclusively from changes in the $\mathrm{pK}$ '. Consequently, the $\mathrm{pH}$ was kept at 6.91 and the temperature was kept at $37^{\circ} \mathrm{C}$ in all three calculations. Correction for the effect of temperature on the $\mathrm{pCO}_{2}$ and use of the correct $\mathrm{pK}$ ' for each temperature and $\mathrm{pH}$ in equation 2 would change the differences shown in this figure and could potentially increase them. Therefore, a variation in the pK' can potentially account for large variations in $\mathrm{HCO}_{3}{ }^{-}$and large differences between serum $\mathrm{TCO}_{2}$ and blood gas $\mathrm{HCO}_{3}{ }^{-}$.

We tested the effect of changing pK' on the differences between serum $\mathrm{TCO}_{2}$ and arterial blood gas $\mathrm{HCO}_{3}{ }^{-}$in the patient presented in this report in two sets of calculations. In the first set, we repeated the calculations of $\mathrm{HCO}_{3}{ }^{-}$using a pK' of 6.1 by the following equation:

$$
\mathrm{HCO}_{3}{ }^{-}=0.0301 \times \mathrm{pCO}_{2} \times 10^{(\mathrm{pH}-6.1)}
$$




\section{Cureus}

In the second set of calculations, we calculated the approximate $\mathrm{pK}$ ' value at a $\mathrm{pH}$ of 6.91 by performing a linear regression on $\mathrm{pH}$ and $\mathrm{pK}$ ' values at a temperature of $37^{\circ} \mathrm{C}$ in Table $1-3$ of the chapter by Madias and Cohen [1]. We obtained the following regression: $\mathrm{pK}^{\prime}=6.410-$ $0.042 \mathrm{xpH}, \mathrm{r}=-0.994$. The $\mathrm{pK}$ ' values calculated by this regression are 6.120 for a $\mathrm{pH}$ of 6.91 and 6.114 for a pH of 7.11. Figure 4 shows $\mathrm{HCO}_{3}{ }^{-}$values reported and calculated from equations 3 and 2 for pK' values of 6.1 and 6.120 in the first set of measurements. The calculated values were substantially higher than the reported $\mathrm{HCO}_{3}{ }^{-}$value and very close to each other and the measured serum $\mathrm{TCO}_{2}$ of $29 \mathrm{mmol} / \mathrm{L}$.

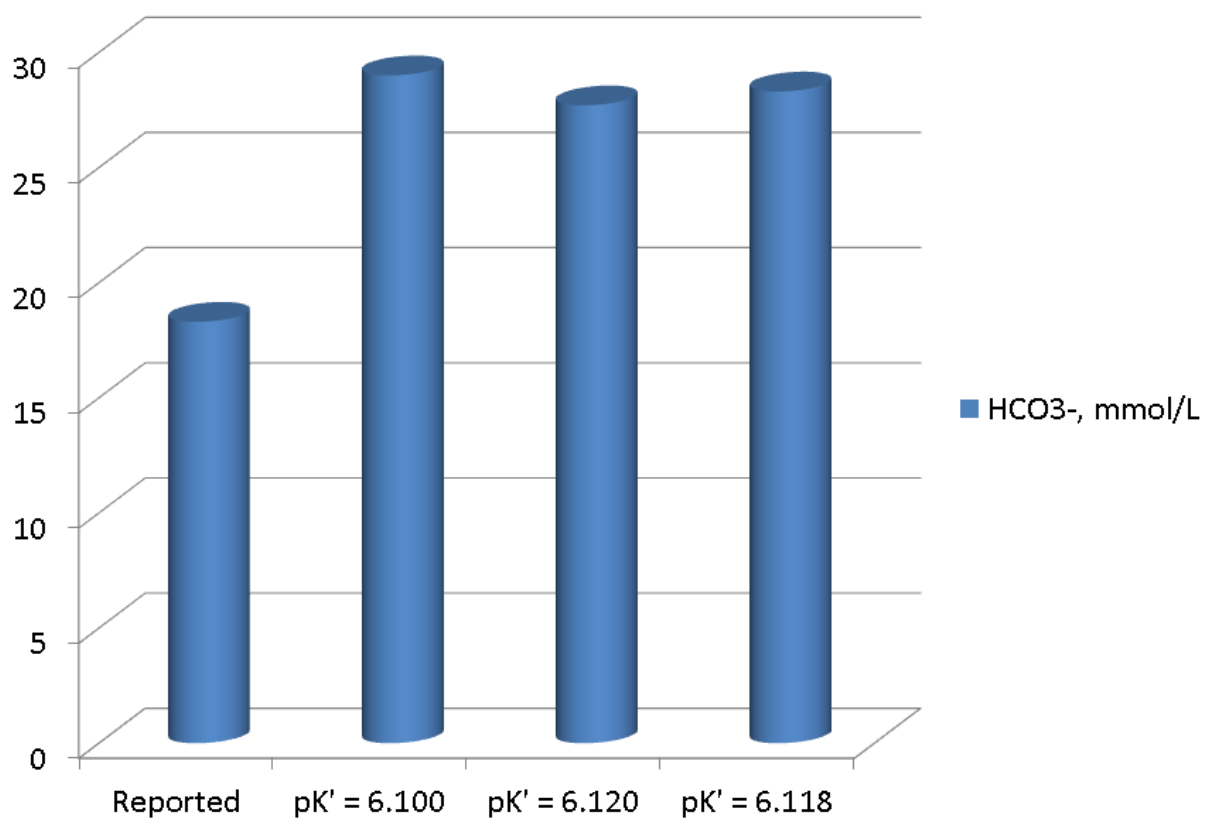

FIGURE 4: Bicarbonate concentrations in the first arterial blood sample reported and calculated by the use of three different pK' values

The three calculated $\mathrm{HCO}_{3}{ }^{-}$values were substantially higher than the reported value and very close to each other and to the measured serum $\mathrm{TCO}_{2}$.

Figure 5 shows $\mathrm{HCO}_{3}{ }^{-}$values reported and calculated from equations 3 and 2 for pK' values of 6.1 and 6.114 in the second set of measurements. Again, the calculated values were substantially higher than the reported $\mathrm{HCO}_{3}{ }^{-}$value and very close to each other and the measured serum $\mathrm{TCO}_{2}$ of $26 \mathrm{mmol} / \mathrm{L}$. 


\section{Cureus}

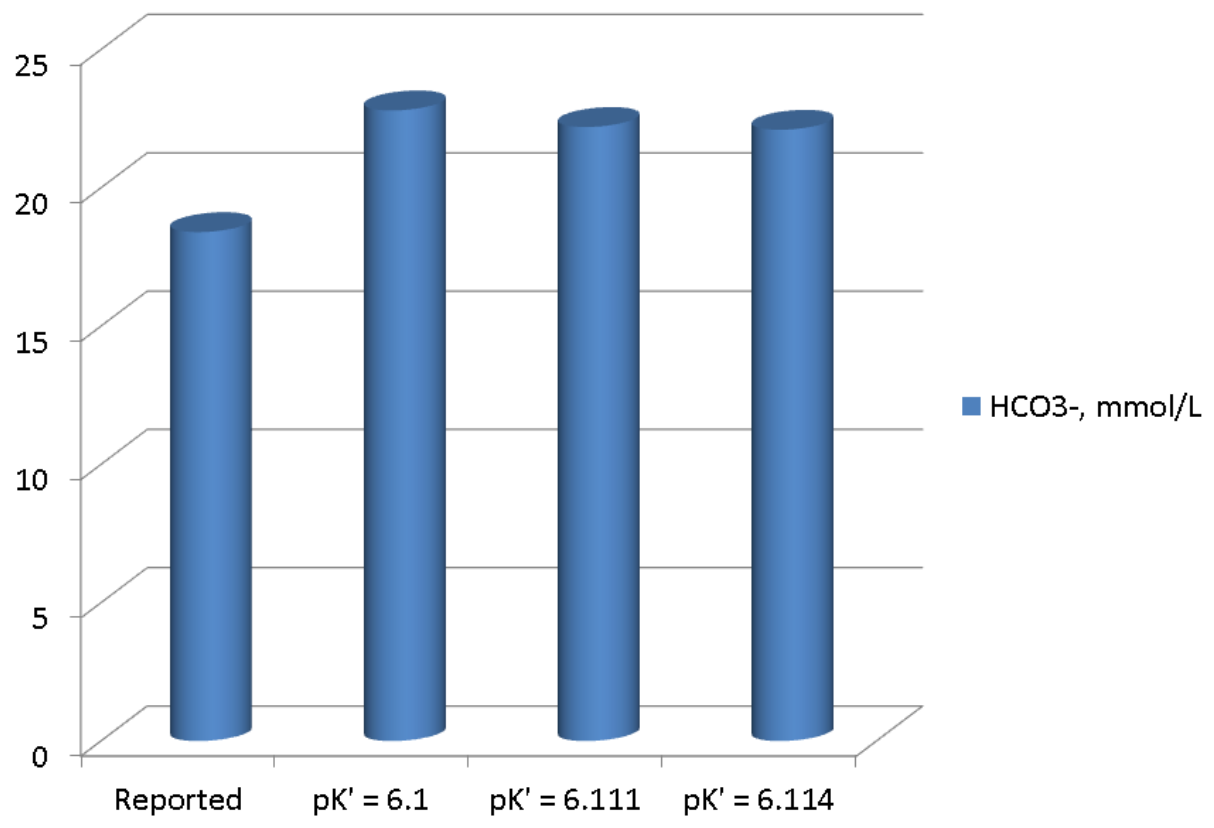

FIGURE 5: Bicarbonate concentrations in the second set of arterial blood gasses reported and calculated by three different pK'.

In the first and second set of blood gasses alike, the calculated $\mathrm{HCO}_{3}^{-}$values were substantially higher than the reported value and very close to each other and to the corresponding measured serum $\mathrm{TCO}_{2}$.

The $\mathrm{pK}$ ' value that is required to obtain an $\mathrm{HCO}_{3}{ }^{-}$of $18.3 \mathrm{mmol} / \mathrm{L}$, calculated from the Henderson-Hasselbach equation for a $\mathrm{pCO}_{2}$ of $149 \mathrm{~mm} \mathrm{Hg}$ and a pH of 6.91 is 6.299, a value substantially higher than any of the values provided in the table published by Madias and Cohen [1]. From equation 1, the $\mathrm{pH}$ value required for the calculation of an $\mathrm{HCO}_{3}{ }^{-}$of 18.3 $\mathrm{mmol} / \mathrm{L}$ at a $\mathrm{pCO}_{2}$ of $149 \mathrm{~mm} \mathrm{Hg}$ is 6.71 when the $\mathrm{pK}$ is 6.1 . We concluded that it is unlikely that the observed difference between serum $\mathrm{TCO}_{2}$ and arterial blood $\mathrm{HCO}_{3}{ }^{-}$was due to variation in the value of $\mathrm{pK}^{\prime}$.

\section{Potential Effect of Instrument Calibration Error or Human Error}

From the previous calculations, we concluded that the reported blood gas $\mathrm{HCO}_{3}{ }^{-}$values were in error. The similarity of the calculated blood gas $\mathrm{HCO}_{3}{ }^{-}$values in the first and second sets of measurements suggested a possibility that the error may be in the algorithms of the blood gas apparatus. We investigated whether the error in the calculations of $\mathrm{HCO}_{3}{ }^{-}$was due to issues related to the blood gas apparatus or to errors of the operators of the blood gas apparatus by 
repeating the calculations using the logarithms for the $\mathrm{pK}^{\prime}$ and $\mathrm{HCO}_{3}{ }^{-}$calculations shown in the manual of the apparatus. At a temperature of $37^{\circ} \mathrm{C}$, the $\mathrm{pK}$ ' values calculated by these algorithms are 6.118 for a $\mathrm{pH}$ of 6.91 and 6.114 for a $\mathrm{pH}$ of 7.11 . Figures 4 and 5 show the calculated blood gas $\mathrm{HCO}_{3}{ }^{-}$values in the first and second set of measurements by the use of these $\mathrm{pK}$ ' values. These values are also very close to the other calculated values and the values of the reported serum $\mathrm{TCO}_{2}$. We concluded that the error in the reported $\mathrm{HCO}_{3}{ }^{-}$values cannot be attributed to the algorithms of the blood gas apparatus.

\section{Discussion}

Acid-base disorders indicate health challenges that must be addressed because they result from profound respiratory or metabolic derangements and can be life-threatening. The first step in the management of an acid-base disorder is a correct diagnosis based on accurate measurement or calculation of the acid-base determinants in the blood and on the proper interpretation of these determinants [8]. The diagnosis is based on the observed combination of the measured value of blood $\mathrm{pH}$ and the measured or computed values of the pivotal carbonic acid/bicarbonate buffer system [9]. The patient presented in this report illustrates the difficulty encountered when measured and computed acid-base parameters lead to different diagnostic acid-base categories. A pathway leading to deciphering this difficulty is detailed.

In the first two sets of serum and arterial blood gas measurements of our patient, substantial differences were found between the reported concentrations of serum $\mathrm{TCO}_{2}$ and arterial blood

$\mathrm{HCO}_{3}{ }^{-}$(Table 1). These differences created differing impressions of the underlying acid-base disorder. The arterial blood gases suggested a picture of mixed respiratory and metabolic acidosis while the combination of arterial $\mathrm{pH}$ and $\mathrm{pCO}_{2}$, plus serum $\mathrm{TCO}_{2}$, indicated acute respiratory acidosis alone [10]. Previous medical history assists in the diagnosis of acid-base disorders [9]. In our patient, previous extensive gut surgery could have been the cause of metabolic acidosis, but his mental status on admission did not allow questioning about recent bowel movements. In any event, the critical issue in this and all other cases with similar findings is an identification of the correct one among the two conflicting acid-base parameters. Variations in the $\mathrm{pK}$ ' of the carbonic acid/bicarbonate system have been extensively studied as a source of $\mathrm{TCO}_{2} / \mathrm{HCO}_{3}{ }^{-}$differences.

Variation of $\mathrm{pK}$ ' with temperature and acidity of the biological fluid tested was documented in both humans [3-6] and animals [11-12]. It was reported that variation in the $\mathrm{pK}$ ' values results in substantial variation of the $\mathrm{HCO}_{3}{ }^{-}$values calculated by the Henderson-Hasselbach equation [13]. Observed differences between serum $\mathrm{TCO}_{2}$ and $\mathrm{HCO}_{3}{ }^{-}$values calculated by using the Henderson-Hasselbach equation with the pK' fixed at 6.1 were attributed to errors in the value of $\mathrm{HCO}_{3}{ }^{-}$secondary to varying $\mathrm{pK}^{\prime}$ [14-20]. This approach suggests that the correct acid-base value for diagnosing the acid-base disorder and assessing its magnitude is the serum $\mathrm{TCO}_{2}$, the measurement of which is not affected by changes in $\mathrm{pK}$ '.

The concept that the bicarbonate/carbonic acid pK' is the main cause of discrepancies between serum $\mathrm{TCO}_{2}$ and blood gas $\mathrm{HCO}_{3}{ }^{-}$has been challenged [21]. One criticism of this concept is that the scale of the $\mathrm{pK}$ ' change that has been calculated for changes in blood acidity and temperature is not large enough to explain large differences between $\mathrm{TCO}_{2}$ and $\left.\mathrm{HCO}_{3}{ }^{-}{ }^{-} 22\right]$. As noted, higher values of pK' resulting from high acidity or low temperature of the solution tested lead to lower values of $\mathrm{HCO}_{3}{ }^{-}$calculated by the Henderson-Hasselbach equation. Studies 
in critically ill patients found only a small variation of the pK' around 6.1 [23-26]. These studies suggest that varying $\mathrm{pK}$ ' is not the cause of large differences between $\mathrm{TCO}_{2}$ and $\mathrm{HCO}_{3}{ }^{-}$.

Another potential source of differences between serum $\mathrm{TCO}_{2}$ and blood gas $\mathrm{HCO}_{3}{ }^{-}$is an analytical overestimation of $\mathrm{TCO}_{2}$ [27]. $\mathrm{TCO}_{2}$ is measured by converting at a temperature of $37^{\circ}$ $\mathrm{C}$ essentially all $\mathrm{CO}_{2}$ in the tested sample to $\mathrm{HCO}_{3}{ }^{-}$by a complex enzymatic method producing $\mathrm{NAD}^{+}$from a known substrate of NADH under the influence of $\mathrm{HCO}_{3}{ }^{-}$. The remaining NADH is measured by reflectance spectrophotometry [28]. A large list of tested medications and organic compounds showed no interference with this assay [29]. However, overestimation of $\mathrm{TCO}_{2}$ was reported in some cases and was attributed to interference by organic acids or carbamino compounds [30-31]. Based on this interpretation of the source of differences between serum $\mathrm{TCO}_{2}$ and blood gas $\mathrm{HCO}_{3}{ }^{-}$, Halperin and coauthors proposed that these differences are not caused by variations in the $\mathrm{pK}$ ' and that the level of $\mathrm{HCO}_{3}{ }^{-}$, rather than that of $\mathrm{TCO}_{2}$, is the correct measurement [32]. In a recent case report, serum $\mathrm{TCO}_{2}$ was consistently low in a patient with normal blood $\mathrm{pH}$ and $\mathrm{HCO}_{3}{ }^{-}$[33]. The presence in the patient's serum of paraproteins causing turbidity and interfering negatively with the enzymatic measurement of $\mathrm{TCO}_{2}$ was identified as the source of the erroneously low $\mathrm{TCO}_{2}$ values in this report.

We evaluated the $\mathrm{pK}^{\prime}$ as the potential source of the difference between serum $\mathrm{TCO}_{2}$ and blood gas $\mathrm{HCO}_{3}{ }^{-}$in the patient presented in this report. The arterial blood $\mathrm{pH}$ in the first set of measurements, at 6.91, was lower than the lowest $\mathrm{pH}$ value in Table 1-3 of the Madias and Cohen chapter [1]. We calculated the $\mathrm{pK}$ ' value for a $\mathrm{pH}$ of 6.91 by performing a linear regression of $\mathrm{pH}$ on the $\mathrm{pK}$ ' values reported in the same table at a temperature of $37^{\circ} \mathrm{C}$. An apparent linearity of the relationship $\mathrm{pK} / \mathrm{pH}$ within “physiologic” $\mathrm{pH}$ values has been reported [34]. Changing ionic strength is the source of a curvilinear relationship $\mathrm{pK} / \mathrm{pH}$ [7]. However, the ionic strength of the blood of our patient was within normal limits. The slope of the $\mathrm{pK} / \mathrm{pH}$ regression that we performed was, at -0.042 , within the range of slopes (-0.05 to -0.04) reported in the literature [17]. The $\mathrm{pK}^{\prime}$ values that we calculated were almost identical to the values calculated by the algorithms of the blood gas apparatus. $\mathrm{HCO}_{3}{ }^{-}$values calculated using a pK' of 6.1 and $\mathrm{pK}^{\prime}$ values calculated from our $\mathrm{pH} / \mathrm{pK}$ ' regression analysis of the Madias and Cohen Table 1-3 and from the algorithms of the blood gas apparatus were very close to each other and to the corresponding serum $\mathrm{TCO}_{2}$ values clarifying the diagnosis of the acid-base disorder and identifying human error as the source of the observed $\mathrm{TCO}_{2} / \mathrm{HCO}_{3}{ }^{-}$differences.

Based on the closeness of the $\mathrm{HCO}_{3}{ }^{-}$values calculated by using a pK' of 6.1 and pK' values obtained by other methods, we propose that the first step in identifying the source of large $\mathrm{TCO}_{2} / \mathrm{HCO}_{3}{ }^{-}$differences should be a recalculation of the blood gas $\mathrm{HCO}_{3}{ }^{-}$value using equation 3 with a pK' of 6.1. This calculation is simple and will provide an easy answer to the question of error. If large differences $\mathrm{TCO}_{2} / \mathrm{HCO}_{3}{ }^{-}$persist after the first recalculation of the blood gas $\mathrm{HCO}_{3}{ }^{-}$, the second step, only in severe hypercapnia, should be to calculate the $\mathrm{dCO}_{2}$ as $0.0301 \times \mathrm{PCO}_{2}$. Persistence of large $\mathrm{TCO}_{2} / \mathrm{HCO}_{3}{ }^{-}$differences should lead to a new calculation of the $\mathrm{HCO}_{3}{ }^{-}$using the algorithms of the blood gas apparatus because they may still reveal substantial differences in extreme acid-base disturbances. Persisting differences, unexplained by changes in $\mathrm{pK}^{\prime}$ or $\mathrm{pCO}_{2}$, require a systematic investigation of the timing of blood gas and 
serum samples in patients with unstable acid-base status and investigation of the handling of the blood samples, with emphasis on the blood gas sample (temperature, time period between drawing and measuring the sample, etc). If sampling issues are discovered, a new simultaneous set of blood gases and serum samples should be obtained. If differences persist in this new set, conditions affecting the measurement of $\mathrm{TCO}_{2}$ should be investigated [30-31, 33].

\section{Conclusions}

Neither a variation in the apparent carbonic acid pK', nor a high PCO 2 value appears to provide adequate explanations for very large differences between measured serum $\mathrm{TCO}_{2}$ and calculated blood gas $\mathrm{HCO}_{3}{ }^{-}$. Although analytical errors in the measurement of $\mathrm{TCO}_{2}$ may be present, the possibility of error in the input of values into the blood gas apparatus or in reporting acid-base parameters should be evaluated first. The first, and simple, step in identifying the source of large differences between serum $\mathrm{TCO}_{2}$ and blood gas $\mathrm{HCO}_{3}{ }^{-}$is an independent verification of the calculation of $\mathrm{HCO}_{3}{ }^{-}$using a pK' of 6.1. Equation 3 should be used as the algorithm for this calculation.

\section{Additional Information Disclosures}

Human subjects: Consent was obtained by all participants in this study. Raymond G Murphy VA Medical Center IRB issued approval. Approved as a case report with waiving of informed consent with the proviso that all identifying information is removed from the text. Conflicts of interest: In compliance with the ICMJE uniform disclosure form, all authors declare the following: Payment/services info: All authors have declared that no financial support was received from any organization for the submitted work. Financial relationships: All authors have declared that they have no financial relationships at present or within the previous three years with any organizations that might have an interest in the submitted work. Other relationships: All authors have declared that there are no other relationships or activities that could appear to have influenced the submitted work.

\section{References}

1. Madias NE, Cohen JJ: Acid-base chemistry and buffering. Acid-Base. Cohen JJ, Kassirer JP (ed): Little, Brown and Company, Boston; 1982. 3-24.

2. Loerting T, Bernard J: Aqueous carbonic acid (H2CO3). ChemPhysChem. 2010, 11:2305-9. 10.1002/cphc.201000220

3. Bradley AF, Severinghaus JW, Srupfel M: Variations of serum carbonic acid $\mathrm{pK}$ with $\mathrm{pH}$ and temperature. J Appl Physiol. 1956, 9:187-200.

4. Alexander SC, Gelfand R, Lambertsen CJ: The $\mathrm{pK}^{\prime}$ of carbonic acid in cerebrovascular fluid . J Biol Chem. 1961, 236:592-596.

5. Maas AH, van Heijst AN, Visser BF: The determination of the true equilibrium constant (pK $1 \mathrm{~g}$ ) and the practical equilibrium coefficient $(\mathrm{pK} 1 \mathrm{~g}$ ) for the first ionization of carbonic acid in solutions of sodium bicarbonate, cerebrospinal fluid, plasma and serum at 25 and 38. Clin Chim Acta. 1971, 33:325-43. 10.1016/0009-8981(71)90490-6

6. Wills MR, Laite PA: Apparent change in the pK1 of carboinic acid in plasma in response to acute metabolic acidosis in normal subjects. Clin Chim Acta. 1971, 35:514-16. 10.1016/00098981(71)90233-6

7. Jungas RL: Best literature values for the $\mathrm{pK}$ of carbonic and phosphoric acid under physiological conditions. Anal Biochem. 2006, 349:1-15. 10.1016/j.ab.2005.08.020

8. Adrogue HJ, Gennari FJ, Galla JH, Madias NE : Assessing acid-base disorders . Kidney Int. 2009, 76:1239-47. 10.1038/ki.2009.359

9. Harrington JT, Cohen JJ, Kassirer JP: Introduction to the clinical acid-base disturbances . Acid- 
Base. JJ Cohen, JP Kassirer (ed): Little, Brown and Company, Boston; 1982. 113-120.

10. Brackett NC Jr, Cohen JJ, Schwartz WB: Carbon dioxide titration curve of normal man. Effect of increasing degrees of hypercapnia on acid-base equilibrium. N Engl J Med. 1965, 272:6-12. 10.1065/NEJM196501072720102

11. Linden RJ, Norman J: The imprecision arising from the application of the HendersonHasselbalch relationship to the blood of anesthetized dogs. J Physiol. 1971, 215:491-507. 10.1113/jphysiol.1971.sp009481

12. Boutilier RG, Iwama GK, Heming TA, Randall DJ: The apparent pK of carbonic acid in rainbow trout blood plasma between 5 and 15 degrees C. Respir Physiol. 1985, 61:237-54. 10.1016/0034-5687(85)90129-X

13. Agabiti E, Todisco T, Grassi V, Sorbini CA: Calculation of plasma bicarbonates using Henderson-Hasselbalch equation. Influence of $\mathrm{pK}$ changes as a function of $\mathrm{pH}$ (article in Italian). Minerva Nefrol. 1973, 20:23-27.

14. Sinclair MJ, Hart RA, Pope HM, Campbell EJM : The use of the Henderson-Hasselbach equation in routine clinical practice. Clin Chim Acta. 1968, 19:63-69. 10.1016/00098981(68)90189-7

15. Tietz NW: Comparison of calculated and experimental pCO2 values. Ann Clin Lab Sci. 1973, 3:341-44.

16. Natelson S, Nobel D: Effect of the variation of pK' of the Henderson-Hasselbach equation on values obtained for total CO2 calculated from pCO2 and pH values. Clin Chem. 1977, 23:76769.

17. Hood I, Campbell EJM: Is pK OK?. N Engl J Med. 1982, 306:864-66. 10.1056/NEJM198204083061410

18. Rosan RC, Erlander D, Ellis J: Unpredictable error in calculated bicarbonate homeostasis during pediatric intensive care: the delusion of fixed pK'. Clin Chem. 1983, 29:69-73.

19. Santoro A, Ferrari G, Spongano M, Cavali F, Zucchelli P: Effects of pK variability on bicarbonate balance in dialysis patients. Artif Organs. 1987, 11:491-95. 10.1111/j.15251594.1987.tb02715.x

20. Rana AP, Rana SP, Rana JP, Kaur T: Base excess significantly corrected for the variations in apparent dissociation constant for human blood gas testing. Indian J Physiol Pharmacol. 2006, 50:303-8.

21. Austin WH: Further comments on the vatiation of pK': computation of [HCO3-] independent of pK' and solubility coefficient. Clin Chem. 1978, 24:1081-82.

22. Gennari FJ: Is pK OK? (Letter). N Engl J Med. 1982, 307:683.

23. Austin WH, Ferrante V, Anderson C: Evaluation of whole blood $\mathrm{pK}^{\prime}$ in the acutely ill patient . J Lab Clin Med. 1968, 72:129-35.

24. De Raedt M, Vandenbergh E, Van de Woestijne KP: Direct and indirect determination of partial pressure of $\mathrm{CO} 2$ in the arterial blood of patients with respiratory insufficiency. Clin Sci. 1968, 35:347-52.

25. Ryan DH, Holt J: Is pK OK?. N Engl J Med. 1982, 307:683-84.

26. Kruse JA, Hukku P, Carlson RW: Constancy of blood carbonic acid pK' in patients during cardiopulmonary resuscitation. Chest. 1988, 93:1221-24. 10.1378/chest.93.6.1221

27. Mohler JG, Mohler PA, Pallivathucal RG: Failure of the serum CO2 determined by automation to estimate the plasma bicarbonate. Scand J Clin Lab Invest Suppl. 1987, 188:61-7.

10.1080/00365518709168174

28. Ortho-Clinical Diagnostics: Instructions for use ECO2. Corning 965 Carbon Dioxide Analyzer Manual. 1977, 1-10. Accessed: October 30, 2015: www.cmmc.org/cmmclab/IFU/CO2_030.PDF.

29. Krower IS, Tholen DW, Garber CC, Goldshmidt HMJ, Kroll MH, Linnet K, Meier K, Robinowitz M, Kennedy JW (NCCLS Document EPG9-A2): Method Comparison and Bias Estimation Using Patient Samples: Approved Guideline, 2nd edition. National Committee for Clinical Laboratory Standards (ed): CLSI, Wayne, PA; 2002.

30. O' Leary TD, Langton SR: Calculated bicarbonate or carbon dioxide?. Clin Chem. 1989, 35:1697-1700.

31. Pichette C, Chen CB, Goldstein M, Stinebaugh B, Halperin M: Influence of solutes in plasma on the total $\mathrm{CO} 2$ content determination: implications for clinical disorders. Clin Biochem. 1983, 16:91-3. 10.1016/S0009-9120(83)90552-0

32. Halperin M, Goldstein MB, Pichette C, Jungas RL, Stinebaugh BJ: Evaluation of the bicarbonate buffer system. Does the pK' really vary in the blood?. Am J Nephrol. 1983, 3:245- 


\section{Cureus}

247. 10.1159/000166723

33. Goldwasser P, Manjappa NG, Luhrs CA, Barth RH: Pseudohypocarbonatremia caused by an endogenous assay interferent: a new entity. Am J Kidney Dis. 2011, 58:617-20.

10.1053/j.ajkd.2011.06.003

34. Hastings AN, Sendroy J Jr: The effect of variation in ionic strength on the apparent first and second dissociation constant of the carbonic acid. J Biol Chem. 1925, 65:445-55. 